\title{
Thermodynamic Modeling of Sustainable Nonferrous Metals Production: Part II
}

\author{
FISEHA TESFAYE @ ${ }^{1,4}$ ALEXANDRA E. ANDERSON, ${ }^{2,5}$ \\ and MINGMING ZHANG ${ }^{3,6}$ \\ 1.-Johan Gadolin Process Chemistry Centre, Åbo Akademi University, Piispankatu 8, \\ 20500 Turku, Finland. 2.-Gopher Resource, 6505 Jewel Ave, Tampa, FL, USA. \\ 3.-ArcelorMittal Global R\&D, East Chicago, IN, USA. 4.—e-mail: fiseha.tesfaye@abo.fi. \\ 5.-e-mail: allieanderson0@gmail.com. \\ 6.—e-mail: Mingming.Zhang@arcelormittal.com
}

Demand for nonferrous metals continues to increase globally, as they are essential in a variety of high-tech applications, including in the renewable energy sector. For example, European manufacturing capacity for Li-ion batteries, which require a substantial amount of metals such as $\mathrm{Ni}$ and $\mathrm{Co}$, is expected to grow by more than 15 times the current capacity by 2025; consequently, the consumption of valuable metals is expected to increase drastically. According to the World Bank Commodities Price Forecast (Fig. 1), the prices of $\mathrm{Sn}, \mathrm{Ni}, \mathrm{Cu}, \mathrm{Zn}$, and $\mathrm{Pb}$ have been increasing since 2016 and are expected to keep rising until 2025. However, the significant disruption in the commodities supply chain due to the COVID-19 pandemic may have short-term fallouts in the forecasted prices.

The global increase in the demand for nonferrous metals has also amplified their recovery from waste streams. In addition to promoting the recovery of resources from waste streams, emphasis is also placed on enabling the prevailing primary resources processing technologies to reduce their environmental footprints and improve their energy efficiency.

In 2020, JOM advisors of the Recycling and Environmental Technologies Committee and the Process Technology and Modeling Committee of TMS organized special topics on Cleaner

The Thermodynamic Modeling of Sustainable Non-Ferrous Metals Production topic was organized by Fiseha Tesfaye, JOM Advisor, Process Technology and Modeling Committee; Alexandra Anderson, Guest Editor, Process Technology and Modeling Committee; and Mingming Zhang, JOM Advisor, Recycling and Environmental Technologies Committee.
Manufacturing of Critical Metals ${ }^{2}$ and Thermodynamic Modeling of Sustainable Nonferrous Metals Production. The latter topic was divided into two parts. Part I constituted articles with a focus on promoting improved and sustainable ways of producing the platinum group metals (PGMs) and rare earth metals (REMs) from different sources. It was published in the July issue of JOM. ${ }^{3}$ For Part II, in the present issue, papers covering experimental investigations, thermodynamic modeling, metallurgical process optimization, resource efficiency, and environmental issues, particularly those pertaining to nonferrous metallurgical processes, were invited, and five articles were approved for publication.

The papers in this topic are primarily devoted to the development of sustainable methods for producing various nonferrous metals such as $\mathrm{Cu}, \mathrm{Sn}, \mathrm{Pb}$, $\mathrm{Au}$, etc. from different sources. The first paper, "Combination of Pyrolysis and Physical Separation to Recover Copper and Tin from Waste Printed Circuit Boards" by Wang et al., proposes a combination of pyrolysis and physical separation to recover both metals and nonmetals from waste printed circuit boards (WPCBs). Based on their experimental investigations, they show that up to $95 \% \mathrm{Cu}$ and $86 \%$ Sn can be recovered from WPCBs.

Two contributions investigated the recovery of $\mathrm{Pb}$ from spent lead-acid batteries. The paper "Recycling of Spent Lead-Acid Battery for Lead Extraction with Sulfur Conservation" by Li et al. proposed a cleaner lead-acid battery (LAB) recycling process via a pyrometallurgical processing route. They present a method for lead extraction from LAB and control of excessive generation of $\mathrm{SO}_{2}$. Xie et al. show in their article entitled "Recovery of Lead from Spent Lead Paste by Pre-desulfurization and Low-Temperature Reduction Smelting" that up to $93 \% \mathrm{~Pb}$ can be 


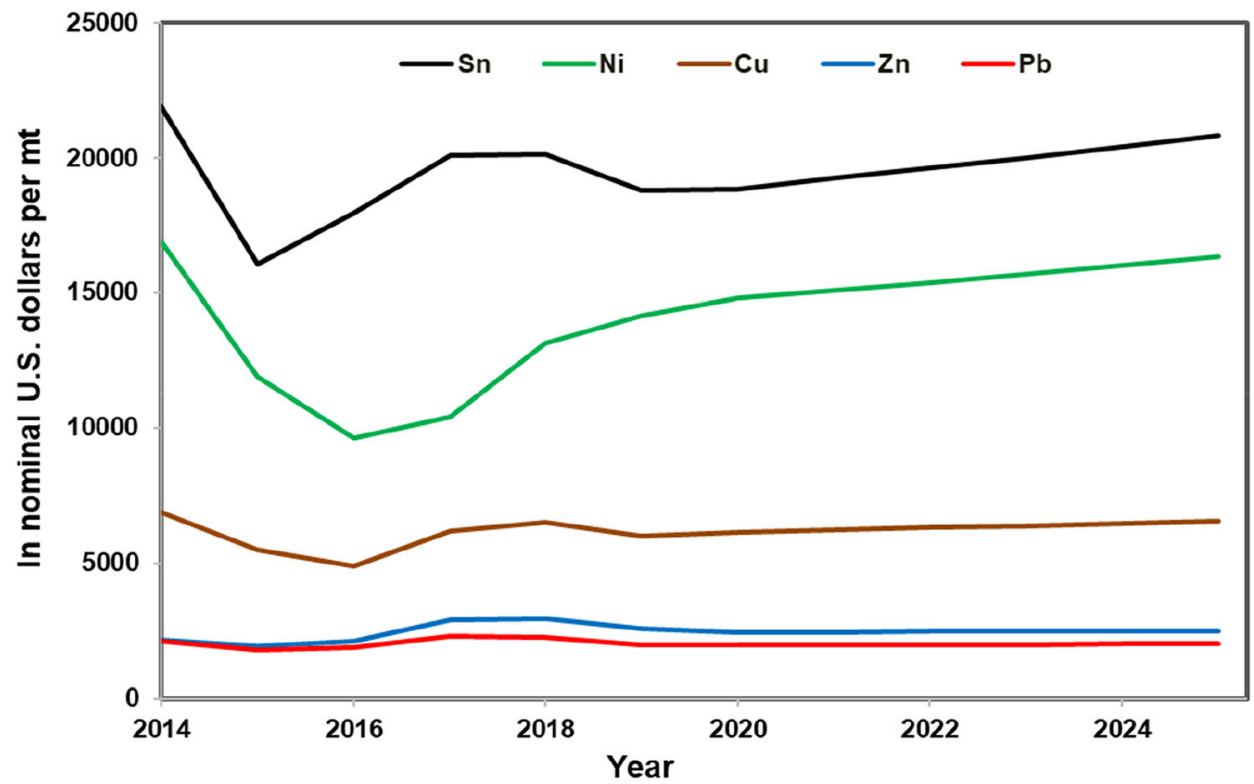

Fig. 1. Average prices of selected nonferrous metals worldwide from 2014 to 2025. Data, including the World Bank Commodities Price Forecast between 2019 and 2025, was adapted from Ref. 1.

recovered from $\mathrm{LAB}$ through a process involving pre-desulfurization followed by low-temperature reduction smelting.

The final two papers in this topic present phase equilibria and thermodynamic modeling of oxide systems in nonferrous metals production processes at high temperatures. The paper "Phase Equilibrium Study of the $\mathrm{CaO}-\mathrm{SiO}_{2}-\mathrm{MgO}-\mathrm{Al}_{2} \mathrm{O}_{3}-\mathrm{TiO}_{2}$ System at $1300^{\circ} \mathrm{C}$ and $1400^{\circ} \mathrm{C}$ in Air" by Shi et al. presents new experimental phase equilibria data at high temperatures that contribute to titaniumcontaining resource processing. The data also update the related thermodynamic databases to enable a move towards digitalization of metallurgical processes. "Thermodynamic Modeling of the $\mathrm{Na}_{2} \mathrm{O}-\mathrm{SiO}_{2}-\mathrm{As}_{2} \mathrm{O}_{5}$ System and Its Application to Arsenic Immobilization Using Glass Formation" by Lee et al. presents thermodynamic modeling of a system that is rather difficult to study experimentally due to its arsenic content. Their thermodynamic assessment utilizes the Calphad methodology to derive the Gibbs energy functions of all relevant phases from room to high temperatures utilizing all available experimental data, as well as previous assessment works. The results reported contribute to safe $\mathrm{Au}$ extraction processes from typical Ascontaining ore minerals.

As such, the articles compiled in this issue should be of interest to a broad readership, including those planning to minimize environmental footprints while promoting sustainable production of nonferrous metals to meet future demands. All titles and authors of the articles published under the topic Thermodynamic Modeling of Sustainable Nonferrous Metals Production: Part II in the September 2020 issue (vol. 72, no. 9) of JOM are listed below.
The articles included in part II can be fully accessed via the journal's page at: http://link.springer.com/ journal/11837/72/9/page/1.

- "Combination of Pyrolysis and Physical Separation to Recover Copper and Tin from Waste Printed Circuit Boards" by X. Wang, F. Jiao, W. Qin, Z. Li, N. Wang, W. Liu, and C. Yang.

- "Recycling of Spent Lead-Acid Battery for Lead Extraction with Sulfur Conservation" by Y. Li, S. Yang, P. Taskinen, J. He, Y. Chen, C. Tang, and A. Jokilaakso.

- "Recovery of Lead from Spent Lead Paste by Predesulfurization and Low-Temperature Reduction Smelting” by B. Xie, T. Yang, W. Liu, D. Zhang, and L. Chen.

- "Phase Equilibrium Study of the $\mathrm{CaO}-\mathrm{SiO}_{2}-$ $\mathrm{MgO}-\mathrm{Al}_{2} \mathrm{O}_{3}-\mathrm{TiO}_{2}$ System at $1300^{\circ} \mathrm{C}$ and $1400^{\circ} \mathrm{C}$ in Air" by J. Shi, M. Chen, X. Wan, P. Taskinen, and A. Jokilaakso.

- "Thermodynamic Modeling of the $\mathrm{Na}_{2} \mathrm{O}-\mathrm{SiO}_{2}-$ $\mathrm{As}_{2} \mathrm{O}_{5}$ System and Its Application to Arsenic Immobilization Using Glass Formation" by J.-H. Lee, S.Y. Kown, P. Hudon, and I.-H. Jung.

\section{ACKNOWLEDGEMENTS}

The organizers of this special topic would like to thank all the authors, co-authors, and reviewers who have contributed to the successful publication of this issue. We are convinced that their expertise has resulted in an excellent issue on this timely topic for JOM. The authors are also grateful to the Academy of Finland (Decision Number 311537) for financial support as part of the activities of the Johan Gadolin Process Chemistry Centre at Ảbo Akademi University. 


\section{REFERENCES}

1. M. Garside, Chemicals \& Resources, Mining, Metals \& Minerals (Statista, 2020), https://statista.com. Accessed 24 May 2020.

2. F. Tesfaye, N. Ma, and M. Zhang, JOM 72, 764 (2020). h ttps://doi.org/10.1007/s11837-019-03976-w.
3. F. Tesfaye, A.E. Anderson, and M. Zhang, JOM 72, 2739 (2020). https://doi.org/10.1007/s11837-020-04217-1.

Publisher's Note Springer Nature remains neutral with regard to jurisdictional claims in published maps and institutional affiliations. 